\title{
FROM CONVENIENT HIBERNATION TO CIRCUMSTANTIAL DESPERATION: HATE SPEECH, PARTY POLITICAL COMMUNICATION AND THE NIGERIA'S 2015 GENERAL ELECTIONS
}

Mike Omilusi ${ }^{1}$

\section{Introduction}

Parties are competing amongst each other for the best ways of resolving political problems. They are in competition for influence and power. Parties not only strive to participate in the formation of political opinion. They also aspire to participate in the representation of the people in parliament. This presumes that parties take part in elections. Besides its candidates, the political programme is the "merchandise" of a party, which it offers to the voters (Hofmeister and Grabow 20II, 9). Thus, the political parties reach out to the voters through organised communication strategies particularly during elections even though electoral campaigns can be very different in different countries and between elections.

As observed by Kavanagh $(2000,29)$ many factors influence the nature of the campaign, including the type of office the election is for; the legislative framework for electoral campaigning (such as electoral laws), cultural habits, and media outreach; the electoral and party systems, etc. Campaign strategies are on the one hand influenced by the political context in which they occur, and on the other hand affected by the political parties who conduct the electoral campaign. However, looking at a political campaign as a discourse, it goes beyond the mere use of words to gain votes. In their bid to persuade, writers of political campaigns dwell on policy utterances which address past deeds, future plans, or general goals as well as character

I Department of Political Science, Ekiti State University, Ado Ekiti, Nigeria. E-mail: watermike2003@yahoo.co.uk. 
comments, which address personality qualities, leadership ability or ideal (Ademilokun and Taiwo 2013, 437).

Political analysts are of the view that hate speech remains one of the features of political campaigns, not only in Nigeria but also in other parts of the world, particularly in Africa. Nigeria's political history, particularly since the first elections held in the country under the 1922 Clifford Constitution, has been experiencing pockets of crisis that could be traced to hate speech, among other anti-social behaviours. For instance, prior to the 2015 General Elections in Nigeria, as observed by Aghadiegwu and Ogbonna (2015, 2), many political watchers, local and international observers and of course the entire citizenry were concerned about the spate of hate speeches that characterized the political campaign messages and adverts of the two main political parties. As a result of this, there was palpable fear that the Nigeria state was on the edge of a precipice.

This may have necessitated the "Abuja Accord," in January 20I5, when all the fourteen presidential candidates signed an agreement, pledging to conduct issue-based campaigns, peacefully accept the electoral results, refrain from using inflammatory language and denounce acts of violence or incitement to violence during the election campaigns. On March 26, the two leading presidential candidates - President Jonathan and General Buhari - renewed their commitments to the Abuja Accord by co-signing a joint pledge for peaceful elections and calling on all Nigerian citizens and party supporters to refrain from violence (NDI 20I5). In spite of the accord, however, political campaigns were characterised with hate speeches, mudslinging and violence in many parts of the country (Hassan 20I4). The political climate in the run-up to the elections was tense and acrimonious, as both the incumbent Peoples Democratic Party (PDP) and the lead opposition party All Progressives Congress (APC), backed by competing opinion polls, predicted victory. The Nigerian rumor and conspiracy mill was in full swing, fuelled by social media and an often politicized news media (Cooke 20I5).

If we look at the research on campaigns at large, one major imbalance has to do with the emphasis on candidates rather than on parties. The typical campaign study, irrespective of whether it is cast in mainly descriptive or theoretical terms, sees the individual candidate as the main vehicle behind any election campaign (Wemaere 1973; Ferejohn and Noll I978 cited in Karvonen I99I). Indeed, in many countries, both in established and newer democracies, the focus- during election campaigns- has always been on the candidates rather than the political parties. However, Karvonen (I99I) argues that "to the extent that there are systematic studies of election campaigns from the point of view of political parties, the campaign as such often receives but secondary attention on the part of the researcher". 
Some pertinent questions have been raised in respect of African parties: What do political parties do between elections? Are African political parties sleeping ghosts that wake up to haunt the goodwill and political resources of the electorates only during election year (if not month) or during election campaigns? Or are they maintaining vigilance and playing their role in democratic governance as the link between citizens, parliament and government? (IDEA 2007, 79). Instead of providing opportunity for public deliberation, African election campaigns are mainly moments for politicians to engage in mass mobilization and manipulation of electoral rules. All too often, campaign strategies feature material inducement and political intimidation (Bratton 2008, I).

As a matter of insight, in Nigeria, when political parties inescapably choose to communicate during electioneering, election promises have always remained the same in content and context since independence. For instance, the rhetorical promises of education, employment, health services, housing, electricity, potable water, rails, roads and other means of transportation are indicators of the state of the country's development in the twenty-first century. The 2015 general elections therefore, offer a unique context to interrogate the place of party political communication in an emerging democracy and specifically how hate campaigns among political gladiators/contending parties could generate violence, and if not tamed, derail the democratic consolidation.

This essay is structured as follows: Following this introduction is the theoretical background to hate speech and party political communication. The third section dwells on a brief reflection of political campaign and politics of hate in Nigeria within the context of past political dispensations. Section four examines the 2015 general elections and the hate speeches it generated essentially among the two major political parties as an institution on the one hand, and among the political gladiators as individuals fronting for their parties, on the other hand. The political and legal preventive measures to stem this ugly trend in future elections are discussed in section five. The last section concludes the essay.

\section{Theorising Party Political Communication and Hate Speech}

\section{Party Political Communication}

Political parties, in spite of their shortcomings, still remain the primary institutional vehicles for political representation, interest aggregation and articulation, and as a constituent mechanism for the formation and organization of government, as well channels for 
maintaining oversight and demanding accountability from governments (Shale 20I0). The communication of political intentions and the search for public consent has always been a part of the main requirements for political leadership in democracy. Since the beginnings of modern party democracy, the conditions and manifestation of communication, however, have changed considerably (Hofmeister and Grabow 20II, 4I). In other words, in modern mass democracies, it is political parties that connect government and the governed with one another: 'Citizens in modern democracies are represented through and by parties' (Sartori I976, 24), which means that communication occurs through political parties and comes from them.

While emphasising the rationale for a communication strategy, the Centre for Multiparty Democracy - KENYA (2012, I) posits that the importance of communication as a management tool cannot be gainsaid. Indeed, success of any political party can be highly enhanced through a clear communication structure that is well known and understood. On their own, brilliant policies and visions cannot guarantee success for a party. They must be supported by purposeful, structured and targeted communication. In essence, communication between leaders and the led never just happens; it must be deliberately organized, developed and built. Voters need to be informed about political programs, policy issues and political alternatives presented by the candidates and political parties (Muturi 20I2, i). All forms of political campaign seek to persuade target audiences by managing the message communicated to them through the media (Stockwell 2004).

Political parties have invested heavily in election campaigning, making full use of new technologies, adapting their organizations and employing specialist agencies and consultants. As a result, the party of today, and the way it operates in the context of electioneering, is a significantly different creature to that of twenty years ago (Farrell and Webb I998, 2I). Parties' communication environments are however, determined by a number of factors: the structure of the mass media, including the composition of the newspaper market and readership; the range of private sector and public service audiovisual channels; the size of the audience reached by newspapers, television, and radio; and the diffusion of new information and communication technologies, such as the Internet and even mobile telephones. The context is also determined by communication policieswhich set out the legal regulation of political communications, especially during election campaigns- exemplified by the rules concerning party fundraising and expenditure, campaign advertising, political broadcasts, and freedom of the media (Norris 2005, 4).

Political parties and leaders are moving towards the new media communication tools for spreading their policies, communicating with 
the people and election campaigning. These newer forms of technology are actively being embraced by the political parties to gain more mileage. The new media technologies have given a new dimension to the political campaign. Many political parties have created their own websites, blogs and Facebook/twitter accounts. They are regularly watching and reading their new media content. (Arulchelvan 20I4, I25). The modern information and communication technologies are now a core element of modern political campaigns. The effective implementation of these sorts of tools is under debate. Politicians in many states have started websites and blogs with a variety of degrees of success. Social software has been used to benefit politicians. Communication of information is usually in paid form and usually persuasive in nature about products, services or ideas by identified sponsors through the various media (Arulchelvan 20I4, I27).

Party campaigns are carried out through a multitude of channels at all societal levels. Nationwide television, regional newspapers and local billboards are used side by side; national party leaders, professional media consultants and local party activists all play significant roles. Just to tell 'the whole story of a campaign' in purely descriptive terms requires so much time and effort that comparisons over time or across systems are normally not attempted. In fact, perhaps the most typical comprehensive account is the journalistic one (e.g. Tyler I987 cited in Karvonen I99I) written shortly after an election to meet a current demand in the market. But even when written by scholars, detailed analyses of election campaigns are frequently presented in the form of descriptive accounts rather than case studies cast in comparative or theoretical terms (Knox I990).

It is however, emphasised that an effective communications program begins at "home," that is, within the party itself. It is an unfortunate truth that too often political parties have poor internal communications. Sometimes, a party does not even have an up-to-date list of leaders and members with their addresses, telephone numbers and other basic information. If a party cannot communicate effectively among its own leaders and members, it is unlikely that a party will be able to realize its potential in the public arena. Both require similar planning, coordination and the capacity to provide accurate, persuasive and timely information (NDI 200I, I9). Generally, campaigners can reach out to the public either via the media or via their own organization. In either case, there is a direct and an indirect channel. With respect to their own organizational channels (or the channels of their allies, which may also be open to them), political actors are likely to increasingly rely on direct communications with the members of their constituencies.

\section{Hate Speech Campaign}


Hate speech is often difficult to identify and prosecute for a number of reasons. For one, free speech is a highly valued right in many countries and is often protected by law. The line separating an inalienable right from a crime can therefore be unclear. Different countries also have different criteria for what constitutes hate speech and for what is legal (The United States Holocaust Memorial Museum 2009, 7). By examining the interrelations between political actors, media institutions and new practices of participatory communication, we can start to examine how extreme speech is (a) in part a product of accelerated competition for public attention, and as such, is shaped by identifiable practices and rituals of communication (b) that "hate speech" has an economic value in a media environment shaped by intensive competition for clicks, hits and "interaction" and that (c) the public contest over what can and cannot be said, a contest often organised around instances of extreme speech, has become a central tactic in and dimension of political positioning in contemporary societies (Tulkens 2013, 9).

Generally, hate speech refers to words of incitement and hatred against individuals based upon their identification with a certain social or demographic group. It may include, but is not limited to, speech that advocates, threatens, or encourages violent acts against a particular group, or expressions that foster a climate of prejudice and intolerance, which can lead to targeted attacks or persecution of that group through 'othering processes' (Gagliardone, Patel and Pohjonen 20I4, 9).In general, definitions of hate speech make reference to a number of the following components: the content of speech; the (written or oral) tone of speech;an evaluation of the nature of that speech; the (individual and collective) targets of that speech; and the potential consequences or implications of the speech act (Titley 20I4, 9). Cohen-Amalgor (20II), for example, offers an extensive definition in the following terms:

Hate speech is defined as bias-motivated, hostile, malicious speech aimed at a person or a group of people because of some of their actual or perceived innate characteristics. It expresses discriminatory, intimidating, disapproving, antagonistic, and/or prejudicial attitudes towards those characteristics, which include gender, race, religion, ethnicity, color, national origin, disability or sexual orientation. Hate speech is intended to injure, dehumanize, harass, intimidate, debase, degrade and victimize the targeted groups, and to foment insensitivity and brutality against them

Hate speech is particularly pernicious and effective because of the way it constructs and politicises in-groups and out-groups. In this context, in-groups refer to the perpetrators of hate speech and the wider 
community that share their views and/or also partake in hate speech; outgroups refer to those groups that are the victims of the hate speech. Ingroups are able to politicise particular social differences (e.g. race, ethnicity, religion, sexual orientation, gender) characterising an out-group in negative and dehumanized terms (Titley 20I4, 9). J.-L. Nancy $(2013,5)$ argues that hatred can go as far as seeking to destroy the other by engaging in acts of elimination. Hatred is, intrinsically, turned more towards action. It is more committed to, or bent on, achieving a result. So, according to Nancy, hatred has an active and 'executive' nature. A hate utterance is itself an act; the thought it expresses is in itself an act of negation.

\section{Political Transition and Politics of Hate in Nigeria: a Reflection}

The history of Nigeria's democratic experiments demonstrates that elections and electoral politics have generated so much animosity which has, in some cases, threatened the corporate existence of the country (such as happened after the annulment of the June I2, I993 presidential election) and in other cases instigated military incursion in to political governance, most notably in I966 and I983s. While assessing the Nigerian electoral process, Richard Joseph $(1987, \mathrm{I} 57)$ describes party politics in the country as a relentless struggle to procure individual and group benefits via the temporary appropriation of public offices eventually reduces the electoral process to a Hobbesian state-of-war.

Although Nigeria has managed to transit from one administration to another, hardly any election conducted in the country has been completely freed of charges of irregularities, electoral malpractices and various degrees of disruptions (Jega 20I0, 3). As emphasised in the report of the Electoral Reform Committee (2008, I48), five key causes can be identified as responsible. Among these are historical context of state creation in Nigeria; the structural imbalance of the Nigerian federation; the nature and character of the Nigerian state and its ruling elites; inter-ethnic competition; and the role of the military and militarization of the polity.

Some scholars attribute the collapse of the first republic to the inappropriateness of the political institutions and processes and to their not being adequately entrenched under colonial rule, whereas others hold the elite responsible. Lacking a political culture to sustain democracy, politicians failed to play the political game according to established rules (see http:// countrystudies.us/nigeria/68.htm). The management and outcome of the I964 federal elections and the I965 Western Regional Election put the 
country on the brink of disintegration and bloodshed with the manifestation of all the centrifugal forces inherent in the body polity. Oyeleye Oyediran (cited in Okereke 20I2) described it as the "signpost to disaster" for the new nation.

During the 1983 elections, political parties and politicians colluded with electoral officials to subvert popular mandate. Political leaders maximally applied the power of incumbency to ensure that they retained power in states where they held sway (Okereke 20I2). The eventual demise of the Second Republic was accelerated by the tension generated by the general elections, which were similar to those of $1964-65$. In several places, violence erupted, and every election was contested in court. A number of the electoral verdicts were rescinded in view of evidence that results were falsified (see http://countrystudies.us/nigeria/68.htm). In a nutshell, empirical data in the First, Second and aborted Third Republic suggest that the attitude of members of the political class left much to be desired in the manner in which they conducted themselves politically (Udogu I995, 216). In his analysis of the country's politics of zero-sum game, Omoh (2013) observes that:

Nigerian politicians are deadly. They employ every means available to cling to power, not for service, but to dispense favour, enrich themselves and secure the future of their unborn babies. It is only in Nigeria that politics is big business. The more you sow either in resources or violence to diminish your opponent, the more the benefit... They act like moving train, whose path no human must cross when it is approaching. They have rendered institutions of state unworkable.

Nigerian democracy has confronted series of challenges with the return to civil rule in 1999 among which include the imposition of candidates, godfatherism, money politics, injustice, lack of party manifestoes and ideology, party indiscipline and so on. The absence of internal democracy among the Nigerian political parties constitutes a major threat to democratic consolidation in the country. This problem, which has led to party defection, otherwise known as cross- carpeting, party witching, floor-crossing, partyhopping, canoe-jumping, decamping and party jumping has remained a permanent feature in the Nigerian democracy (Abimbola and Adesote 2012: 46).Most platforms for debates and other political communication are turned into platforms for verbal threats, insults, intimidation, coercion, blackmail and hate speech. Political campaigns in Nigeria, either verbal or written, are typically characterized by these uninhibited discursive behaviours (Ademilokun and Taiwo 2013, 438).

Election activities come with different expectations from the politicians, electorateand thegovernmentamong other stakeholders (Olurode 
20I4, 72). Over the years, the politicians have become more desperate and daring in taking and retaining political power; more reckless and greedy in their use and abuse of power; and more intolerant of opposition, criticism and efforts at replacing them (Electoral Reform Committee 2008, I9). General elections have always been accompanied by violence (International Crisis Group 20I4). The logic of Nigeria's party politics is that powerful and rich political entrepreneurs seek to exclude popular candidates from their parties so that they could get an undeserved nomination for an election that would be won on the basis of rigging (Ibrahim and Aturu 2009, 35).

Frau (2008) argues that for free, fair and equitable elections to be achieved, certain acceptable elements must be put in place and these include: an equitable and fair electoral framework; a professional neutral and transparent election administration; a generally accepted code of ethical behaviour in political and press freedom; accountability of all participants; integrity safeguard mechanism and the enforcement of the election laws and other relevant laws. But as could be deduced from the foregoing, these attributes are alien to electoral politics in Nigeria as the "practitioners of perversion of the popular will through competitive election rigging have shown considerable skills in out manoeuvring themselves or in circumventing the law and in creating new or newer forms of electoral fraud" (Ibrahim and Aturu 2009, 43).

\section{Conceptualising Hate Speech Campaigns within the Context of the 2015 General Elections}

During electioneering, parties and campaign organisations do employ different strategies to woo voters and discredit their opponents, including attack advertisements as witnessed in the 2015 general elections. According to Ogwezzy-Idisika (quoted in Premium Times, May 8, 20I5), the 2015 presidential campaigns were much about hate speeches and devoid of concrete agenda beyond the promises of water, roads, free education and security.Apparently disturbed by the development ahead of Nigeria's 2015 election, Fatou Bensouda, prosecutor of the International Criminal Court, ICC, for the second time, reminded Nigerian politicians that they risked being taken to The Hague, Netherlands, for trial if they continued with the level of violence already witnessed in the country (See RealNews, March 30, 2015).

For instance, the PDP campaign was characterized by hate campaigns against Mr. Buhari with little emphasis on the achievement of Mr. Jonathan. As shall be explained in the next section, some of the most 
horrific attacks against Mr. Buhari "came from the president's wife, Patience Jonathan, the governor of Ekiti State, Ayo Fayose, and the spokesperson for Mr. Jonathan's campaign team, Femi Fani-Kayode" (Premium Times, May 4, 20I5). Indeed, as attested to by the party spokesperson, Olisa Metuh, after the election, the party headquarters was sidelined during the campaigns, and that "overzealous" persons were allowed to run a hate campaign against Mr. Buhari, thereby making the former military ruler more popular (ThisDay, May 5, 20I5). Kukah (2015) captures the pre-election campaigns more succinctly:

The 2015 General elections have been turned into a theatre of hate speeches and campaigns coloured in a form that defies logic and common sense. Various politically motivated hate speeches about various candidates and especially the two leading Presidential candidates of All Progressives Congress and People's Democratic Party have been bandied. I am sure if experts should collate analyses of contents of the social media this year, Nigeria will rank top because arguably more than 40 million young Nigerians who have since graduated and have no means of livelihood have found solace in the various social media platforms and are busy churning out divergent messages.

Reports from the WANEP-Nigeria early warning analysis of risk factors across flashpoint states between July and December 20I4, showed increasing levels of direct attacks by parties on opposition's existing structures in the form of destruction of party property, the defacing of billboards and campaign structures, destruction of vehicles, bomb explosions at rallies and burning of party secretariats e.t.c. (ThisDay, February I2, 20I5).In addition to physical attacks, hate speeches, negative advertorials and propaganda ominously became dominant in the actions of politicians and political parties throughout the electioneering. Some of the outstanding cases are discussed here.

\section{Political Parties (PDP versus APC)}

Obviously, prior to the general elections, there was palpable tension in the country. The media was awash with campaigns by the different political parties especially the ruling party- PDP and the major opposition party- APC. Some of the campaigns were seen as campaign of calumny (Aghadiegwu and Ogbonna 2015, 3). There were allegations and counterallegations from different quarters, many of them unsubstantiated. For instance, there were accusations by the Northern leaders and even the opposition party that Jonathan-led Federal Government was fueling the Boko Haram insurgency in the North East. Reminiscent of the Rwanda genocide, the state governor of Katsina was caught on tape referring to 
opponents as "cockroaches" and encouraging his supporters to crush them while they chanted "kill them"(Hassan 20I4).

The PDP maintained that the ideology of the APC was the same as Janjaweed as well as the anti-Balaka and the Seleka of the Central African Republic whose ideology are completely anarchists (This Day, March Io, 20I4)and that the APC was out to cause confusion and ultimately truncate the nation's democracy: "in continuously hauling insults against a democratically elected President upon whose shoulders lies the sacred mandate freely given by the Nigerian people, the APC is directly insulting Nigerians and showing their disdain for the institution of democracy. This further confirms the APC's Janjaweed ideology against the nation...In constantly criticizing every strategy adopted by the President in the war against terrorism, the APC has not only confirmed its preference for insurgency but also exposed its underlining design to distract the government and frustrate the overall anti-terrorism efforts"(Vanguard, May 27, 20I4). Janjaweed, as Lai Mohammed remarked, has a disturbing religious connotation; not to talk of its settled place in infamy, given its murderous havoc on co-Sudanese, who just disagree with the extant government (The Nation, March I4, 20I5).

When the APC presidential candidate saw it expedient to travel to the UK in the wake of the postponement of the general elections, the PDP, through its campaign organization spokesperson, Femi Fani-Kayode, accused the All Progressives Congress (APC) of trying to force a dying man into office to achieve ulterior motives. He said the leaders of the APC knew that its presidential candidate, Muhammadu Buhari had "prostate cancer, acute asthma and that he suffers from dementia” and as such wouldn't last long in office if elected (Peoples Daily, March 9, 2015).However, no proof was shared to support these claims (Omotola and Nyuykonge 2015, 7).

Many inciting comments came from the opposition party (APC) too. For instance, the party once called on the then ruling People's Democratic Party, PDP, and the federal government to jettison its plan to assassinate General Muhammadu Buhari, its presidential candidate. Lai Mohammed, national publicity secretary of the APC, who made the allegation in a newspaper interview, claimed the PDP-led government had security men specially trained as snipers to eliminate those opposed to President Goodluck Jonathan's re-election bid. Mohammed said: "I have never seen a government so terrified of elections as this present administration...coming to issue of security, they have made an attempt on his (Buhari) life once before; it can be done again. But, let us warn them that any attempt on the life of Buhari or Bola Tinubu will lead to a consequence that will be very dear for this country. They should not even contemplate it" (RealNews, March 30, 2015). 
While the APC allegation was still simmering, Ejike Mbaka, a Catholic reverend father based in Enugu, during a church service on March I5, alleged that President Goodluck Jonathan and his wife were planning to kill him over his criticism of the federal government and for his opposition to the president's re-election.Before the 2015 elections, Mbaka had "instructed his teeming congregation to vote out Goodluck Jonathan from office because the incumbent president has failed Nigerians on all scores: security, alleviation of poverty, and fight against corruption" (Ukah 2015).There were allegations that Mbaka was pressured by the opposition All Progressives Congress (APC) and the Roman Catholic Church into turning his back on Jonathan. A month before his scathing criticism of the President, Mbaka had predicted Jonathan would be re-elected (The City Reporters, Jan 5, 20I5).

\section{Political Gladiators and Candidates}

A number of the advertisements published by some political parties and politicians were reckless and inciting while others were scandalous in every material particular (Falana 2015). For instance, Ayodele Fayose, the Ekiti State governor, who literally assumed the position of his party spokesperson, embarked on what many political observers described as crude and barbaric antagonistic campaign of calumny against the opposition party. Fayose once bought the front pages of The Punch and The Sun Newspapers not only to pass a death sentence on Buhari because the man was 72.He used the same medium to mock dead leaders from a section of the country. His invective and acid sarcasms targeted at the presidential candidate of the All Progressives Congress (APC), General Muhammadu Buhari, may have left some Nigerians in consternation nay, bewilderment, but to many others, the Ekiti State Governor was merely treading his familiar terrain of controversy (Omilusi 20I5).

The advert, which had the pictures of Murtala Mohammed, Sani Abacha, and Umaru Yar'Adua - past Nigerian presidents who died in office - was accompanied by excerpts from the Bible book of Deuteronomy 30 verse I9. "Nigerians be warned! Nigeria...I have set before thee Life and death. Therefore, choose life that both thee and thy seed may live," it said, suggesting that Buhari represents death while his rival, President Goodluck Jonathan represents life. The advert went ahead to put a huge question mark over the picture of Mr. Buhari, which was placed beside the pictures of the late leaders. The advert asked its readers: "Will you allow history to repeat itself? Enough of State burials". The chairman of the National Human Rights Commission, NHRC, Chidi Odinkalu, decried the death wish publication by the advertiser. He said it offended public decency and 
violated all known norms of decorum (Vanguard, January 22, 20I5).

Similarly, former militant and leader of the Niger Delta Peoples Volunteer Force (NDPVF), Mujahid Asari-Dokubo, once declared that President Goodluck Jonathan's presidential ambition in 2015 was already settled, as his Niger Delta compatriots would not succumb to any force opposed to its full actualization. He threatened: "There would be blood in the streets if Mr. Jonathan is not reelected president in the 2015 election" (Premium Times, Sep 9, 2013). Many ex-militant leaders in the region, sharing Asari-Dokubo's stand, threatened to violently cripple the petroleum industry, and a group of former militants threatened to cut off the supply of petroleum products to the north, if Jonathan was not re-elected (ICG 20I4, 5).On another occasion, Asari-Dokubo declared that: "For every Goliath, God created a David. For every Pharaoh, there is a Moses. We are going to war. Every one of you should go and fortify yourself" (Osun Defender, Jan 29, 2015).

On his part, in a congratulatory message to Nigerians towards the end of 20I4, the APC chairman, John Odigie-Oyegun, noted that: "As a party, we assure you that we will congratulate president Goodluck Jonathan and his party, PDP if our presidential candidate and party are defeated in free and fair elections, and we will not go to court...However, as a party, we wish to reiterate, that we will not hesitate forming a parallel government, if the 2015 elections are rigged either by the use of security agencies (police or military) to harass, intimidate and cajole voters or through the use of a compromised Independent National Electoral Commission, (INEC)" (Osun Defender, Jan 29, 20I5). In April 20I4, Bola Tinubu, another APC leader, warned: "It is going to be rig and roast. We are prepared, not to go to court but to drive you out .... For every action, there will be a reaction" (Tell, July 7, 2014 cited in ICG 20I4, 7). In July, Akwa Ibom state Governor Godswill Akpabio threatened opposition politicians (and dissident members of his party): "those who want to take power through the back door will die. They will die! And the PDP will continue" (ThisDay, July 25, 20I4).

Doyin Okupe, Senior Special Assistant to President Goodluck Jonathan on Public Affairs also described the All Progressives Congress presidential candidate as a religious bigot. Okupe then wrote on his Twitter page that: "Buhari is a religious bigot and there is nothing he can do about that. He is not even a nationalist” (NigerianEye, December I7, 20I4). Similarly, a Blackberry Messenger (BBM) statement by Deji Adeyanju, an official in the Office of the Senior Special Assistant to the President on Public Affairs, Doyin Okupe, said: "Buhari can never be President of Nigeria. Quote me any day any time. Instead of Buhari to become President of Nigeria, Nigeria would rather break. A military coup will even be allowed than for Buhari to 
become the president of a democratic Nigeria, quote me any day, any time" (Premium Times, January I7, 20I5).In a petition dated January 30, 2015, the APC drew the attention of the National Broadcasting Commission (NBC) to what it described as "the ongoing mischievous, fabricated, defamatory and hate documentary broadcasts by African Independent Television and Nigerian Television Authority against All Progressives Congress and its presidential candidate, General Muhammadu Buhari” (The Sun, February 2, 20I5). The PDP had sponsored a documentary in the two media houses prior to the election.

For Patience Jonathan, her speeches during the campaign were described as "outrageous, mindboggling and unbecoming of a woman of such exalted position" (See Daily Times, March I8, 20I5). Mrs. Jonathan, whose husband was the presidential candidate of the People's Democratic Party, PDP asked supporters of her husband to "stone" anyone who chanted the APC's change mantra. The call by Mrs. Jonathan was made at a rally in Calabar, Cross River State during a PDP political rally (Vanguard, March 9).The First Lady was inciting people to be violent during the campaigns. She also brazenly insulted the people of the North and a former Head of State without due regard to the party chairman, who is from the North (Abubakar Tsav, Daily Post, March 6, 2015).

At a PDP women presidential campaign rally in Kogi State, Mrs. Jonathan, appealed to Nigerian women to vote en masse for the People's Democratic Party (PDP) during the presidential election because the brain of the All Progressives Congress (APC) presidential candidate, General Muhammadu Buhari (rtd), is dead: "Wetin him dey find again? Him dey drag with him pikin mate.

Old man wey no get brain, him brain don die pata pata," she said in Pidgin English (This Day, March 4, 20I5). This was later rationalized by the Director of Media and Publicity of the PDPPCO, Femi Fani-Kayode who noted that: "To say that General Buhari is "brain dead" is an understatement and to suggest that he is suffering from dementia is nothing new. The First Lady has spoken in a courageous and forthright manner and, most important of all, she has spoken the bitter truth. Instead of crying like spoilt little brats and complaining, the APC and the Buhari Campaign Organisation should live with that bitter truth and leave her alone" (Premium Times, March 5, 20I5).

\section{Political and Legal Preventive Measures}

Despite the ambiguous status of hate speech in the academic 
world, its negative implications for society are clear to everyone. According to Leets (2002), hate speech violates the individual's dignity, resulting to humiliation, distress and psychological or emotional pain. Likewise, Downs and Cowan (2012) mentioned in their study that hate speech has been a strong weapon that could harm individuals by degrading, terrorizing, wounding and humiliating them.

From 'comments' on social media platforms to one on one discussions on ethnic, political and religious issues and also provocative statements in the media by political, community, ethnic and religious leaders, it has become clear that hate speech is gradually becoming a menace in the society (Sekyen Dadik 20I5). Hate speech is not simply a concern for media professionals; it affects entire communities and therefore response mechanisms need to engage many people. Leaders play a crucial role when they deploy hate speech, but they can also condemn it when it occurs, even from nonofficial sources. Silence in the face of hate speech can indicate that it- and any violence it promotes- is acceptable (The United States Holocaust Memorial Museum 2009, 9).

Thus, politicians and other public figures have a greater responsibility because they have broader possibilities for spreading prejudice against certain groups. Moreover, the impact of political speech is also greater because politicians are in a position of authority: so hate speech has an impact on potential offenders who feel encouraged in their intolerance and bias. In some countries, it has been said that criminal legislation has an added responsibility if the author of hate speech holds public office (Tulkens 2013, 9).

In any democratic nation, the right to freedom of speech and expression should necessarily accompany restrictions against the incitement of masses towards violent conclusions. It is the responsibility of the State to ensure safety and welfare of the masses over the right to expression of a single person, or groups of persons, for that matter (Dhakal 20II).Also, the danger of misuse of government power for campaigning purposes can be limited if laws and regulations are in place to regulate the role of the media in the election campaigns. Thus, legal framework reforms have been advocated as a panacea to election-related violence as may be instigated by the activities of the stakeholders including those who get involved in hate campaigns.

This involves providing assistance in the design and implementation of legal frameworks so as to reduce underlying drivers of violence. It is crucial to develop a legal framework that has broad support among competing parties and candidates. Rao, drawing from the submissions of the USAID (2013) argues that the legal frameworks most relevant for electoral security are 
those from: constitutions; peace agreements; electoral legislation; women's protection and equality legislation; and, land ownership legislation. Each of these legal instruments can intersect with electoral security.

Notable attempt to ensure sanity in the electoral process in Nigeria was initiated after the 2007 election by late President Umaru Musa Yar'Adua who set up an Electoral Reform Panel, headed by the former Chief Justice of the Federation Mohammed Uwais. The panel later reviewed the country's electoral machinery and recommended ways through which electoral irregularities could be rectified in Nigeria. The final report was received by the government, even though some parts of the report were not implemented by the government (Hassan and Musa 2014, 339).

The fundamental right to freedom of expression including freedom to hold opinions and to receive and impart ideas and information without interference has been guaranteed by the Constitution. (Section 39 of the Constitution). Apart from professional ethics the law of defamation protects the reputation of individuals and corporate bodies including politicians and political parties. Since freedom of expression is not absolute any media house or reporter who engages in libelous publications during electioneering campaigns may be sued and if found liable, ordered by the courts to pay damages running to millions of naira (Falana 20I5).

In addition to the penal codes, the Electoral Act 2010, as amended, has prohibited political campaigns, which are based on hate or incitement. According to the Nigerian Electoral Act 20IO, Section 95 (I), 'A political campaign or slogan shall not be tainted with abusive language directly or indirectly likely to injure religious, ethnic, tribal or sectional feelings.' Section 95 (2) states that 'Abusive, intemperate, slanderous or base language or insinuations or innuendoes designed or likely to provoke violent reaction or emotions shall not be employed or used in political campaigns.' In order to ensure equal coverage of the activities of political parties and candidates, the Act has criminalised certain publications with respect to political reporting.

\section{Conclusion}

In view of the foregoing analysis, this essay suggests that the citizens and other stakeholders should imbibe the culture of democratic values. However, for democratic values to be passed on to the members of a given society, "formally or informally, the political culture within a given country should be conducive to democratic ideals" (Konrad-AdenauerStiftung 20II, II).There is the need to effectively regulate behaviour and actions of contestants, voters, officials, etc in the entire electoral process and 
to carefully frame rules and regulations covering all aspects of the electoral process (Electoral Reform Committee 2008, 6I). Politicians should conduct their campaign on the basis of issues rather than attack on personalities or mobilisation of religious, ethnic and regional sentiments (Alemika 20II) as witnessed during the 2015 general elections.

Contemporary discourse of liberal democracy recognises the place of a free and fair electoral process as a critical component of any effort to enthrone a democratically responsive and development-focused government. As Ronald Dworkin (I990) posited: “True democracy is not just statistical democracy, in which anything a majority or plurality wants is legitimate for that reason, but communal democracy, in which majority decision is legitimate only if is a majority of equals. That means...that each individual person must be guaranteed fundamental civil and political rights no combination of other citizens can take away, no matter how numerous they are or how much they despise his or her race or morals or way of life. That view of what democracy means is at the heart of all the charters of human rights".

The spirit of tolerance is particularly important during a period of transition to democracy, in order to entrench the values and practices of democracy at a time when a new political order is being established. This spirit is enhanced if: the opposition recognizes the right and responsibility of the Government to undertake the administration; and the Government recognizes the right of the opposition to criticise government policy and administration, to offer alternative ideas and policies, and to lobby for them (IDEA 200I, 46).In the final analysis, however, it is also pertinent that various stakeholders must play by the rules of the game because due adherence to constitutional and electoral stipulations is fundamental to the credibility of elections and, in the long run, democratic consolidation.

\section{REFERENCES}

ACE Encyclopedia. 20I2. "Parties and Candidates", The ACE Electoral Knowledge Network, www.aceproject.org

Ademilokun, Mohammed and Taiwo, Rotimi. 2013. "20II elections Discursive strategies in newspaper campaign advertisements for Nigeria's", Discourse Q Communication 7(4) 435 -455.

Aghadiegwu, Ukwueze and Ogbonna, Uche A. 2015. "The Rise of Hate and Peace Journalism in The Nigerian Democratization Process: The Place of The New Media", Communication Panorama African and Global Perspectives, Volume i Number I Sept-Oct 20I5 Maiden Issue 
Alemika, Etannibi EO. 20I5. Post-Election Violence in Nigeria: Emerging Trend and Lessons. http://cleenfoundation.blogspot.com.mt/20II/07/ post-election-violence-in-nigeria.html

Biegon, Japhet. 2009. Electoral violence and fragility in Africa: Drawing Lessons from Kenya's Experience in the 2007/2008 Postelection Violence, Paper for Presentation at the Poster Session of the Conference on 'Financial Markets, Adverse Shocks and Coping Strategies in Fragile Countries', Accra, Ghana, 2I23 May 2009.

Blunder, G. (ed.). 1983. Communicating to Voters: Television in The First European Parliamentary Elections. London: Sage.

Brants, Kees and Voltmer, Katrin. 20II "Introduction" in Brants and Voltmer (eds.) Political Communication in Postmodern Democracy: Challenging the Primacy of Politics, New York, Palgrave Macmillan.

Bratton, Michael. 2008. "Vote Buying and Violence in Nigerian Election Campaigns". Afrobarometer Working Paper No. 99.

Centre for Multiparty Democracy - KENYA. 20I2. Creating Effective Party-Based Communication: A Guideline for Preparing a Communication Strategy for Political Parties. http://dipd.dk/wp-content/uploads/Creating-Effective-Party-Based-Communication-A-Guideline-for-Preparing-a-Communication-Strategy-for-Political-Parties.-CMD-Kenya-Oct.-20I2.pdf

Cohen-Amalgor, Raphael. 20II. "Fighting Hate and Bigotry on the Internet". Policy and Internet, Vol. 3(3).

Collier, Paul, and Pedro C. Vicente. 2012. "Violence, Bribery, and Fraud: The Political Economy of Elections in Sub-Saharan Africa". Public Choice, I53(I-2), pp. II7-I47.

Cooke, Jennifer. 20I5. Nigerians Have Voted, Will Political Leaders Listen? The Center for Strategic and International Studies. http://csis.org/publication/nigerians-have-voted-will-political-leaders-listen

Dadik, Sekyen. 2015. "Hate Speech in Nigerian Media: Which Way to Go". Africa Prime News, March 27.

Daily Times. 20I5. NGO Condemns Patience Jonathan's Hate Speech, March I8

de Vreese, Claes H and Elenbaas, Matthijs. 20ıı. "Spin and Political Publicity: Effects on News Coverage and Public Opinion" in Brants and Voltmer (eds.) Political Communication in Postmodern Democracy: Challenging the Primacy of Politics, New York, Palgrave Macmillan

Dhakal, Ankit. 20II. "Hate-Speech: Judicial Regulation Over the Right to Freedom of Speech and Expression”. Spotlight News Magazine, Vol. 
05 No. 05 Aug. I9-201I.

Downs D.M. and Cowan, G. 20I2. "Predicting the Importance of Freedom of Speech and the Perceived Harm of Hate Speech". Journal of applied Social Psychology, 42, 6, pp. I353-1375.

Dworkin, Ronald. I990. A bill of Rights for Britain. London, Chatto and Windus.

Falana, Femi. 2015. "Legal and Ethical Issues in Reporting 2015 Elections”. This Day, February 4.

Farrell, David and Webb, Paul. I998. Political Parties as Campaign Organizations, Paper was presented to the project meeting on "Unthinkable Democracy," directed by Russell Dalton and Martin Wattenberg and held under the auspices of the University of California's Centre for the Study of Democracy, March I3-I4, I998

Frau, N. A. 2008. The Cameroon Electoral System, Processes and Outcomes through the Prism of the Performance of the Government and Opposition Parties. CODESRIA Small Grants Programme for Thesis Writing 2008, Maîtrise Political Science University of Yaoundé II

Gagliadone, Iginio, Patel, Alisha and Pohjonen, Matti. 20I4. Mapping and Analysing Hate Speech Online: Opportunities and Challenges for Ethiopia. http://pcmlp.socleg.ox.ac.uk/wp-content/uploads/2014/ı2/ Ethiopia-hate-speech.pdf

Hassan, Idayat. 20I4. Nigeria Forum: Why are the Stakes so High for the 2015 Elections? http://africanarguments.org/2014/12/16/nigeria-forumwhy-are-the-stakes-so-high-for-the-2015-elections-by-idayat-hassan/

Hassan, N. A. and Musa, A. 20I4. Ecology and Dynamism of Nigerian Government and Politics. Kaduna: Pyla-mac Services

Hirsch, Susan F (n.d) "Putting Hate Speech in Context: Observations on Speech, Power, and Violence in Kenya" Paper prepared for the Holocaust Memorial Museum conference on Speech, Power, and Violence. http://www.ushmm.org/genocide/spv/.

Hofmeister, Wilhelm and Grabow, Karsten. 20II. Political Parties Functions and Organisation in Democratic Societies. Singapore, Konrad Adenauer Stiftung.

Howard, Ross. 2005. Media and Elections: An Elections Reporting Handbook. Vancouver: IMPACS.

Ibrahim, Jibrin and Aturu, Bamidele. 2009. "Rigging and Electoral Fraud in Nigeria: State of the Art" in Ibrahim and Ibeanu (eds.) Direct Capture the 2007 Nigerian Elections and Subversion of Popular Sovereignty. Centre for Democracy and Development. 
International Crisis Group. 20I4. "Nigeria's Dangerous 20I5 Elections: Limiting the Violence". Africa Report $\mathrm{N}^{\circ} 220 \mid$ 2I November 2014.

International IDEA. 200I. Democracy in Nigeria: Continuing Dialogue(s) for Nation-building, International Institute for Democracy and Electoral Assistance.

. 2007. Political Parties in Africa: Challenges for Sustained Multiparty Democracy. International Institute for Democracy and Electoral Assistance.

Joseph, Richard. 1987. Democracy and Prebendal Politics in Nigeria: The Rise and Fall of the Second Republic. Cambridge, Cambridge University Press

Just, Marion R. et al. I996. West, Crosstalk: Citizens, Candidates, and the Media in a Presidential Campaign. Chicago: University of Chicago Press.

Kambudzi A. 2008."Turning elections into a development asset in Africa' ISS Paper 163.

Karvonen, Laur. I99I. “The Study of Election Campaigns: An Introduction”. Scandinavian Political Studies, Vol. I4 - No. 3, I99I, Nordic Political Science Association.

Kavanagh, Deis. 2000. “Campaigning”, in: Rose, Richard (Ed.): International Encyclopaedia of Elections. London: Macmillan, 29-3I

Knox, C. I990. "Election Campaigning - A Case Study of the I989 N. Ireland Local Government Elections". Paper Prepared for the ECPR Joint Sessions, Bochum, Germany, 2-8 April I990

Kukah H. 20I5. Hate Speech, Social Media and The 2015 Election. pointblanknews.com/pbn/.../hate-speech-social-media-2015-election/

Leets, L. 2002. "Experiencing Hate Speech: Perceptions and Responses to Anti Semitism and Antigay Speech". Journal of Social Issues, Vol. 58 , No. 2, 34I- 36I

James Lo, Sven-Oliver Proksch and Jonathan B. Slapin. 20I4. "Ideological Clarity in Multiparty Competition: A New Measure and Test Using Election Manifestos". British Journal of Political Science, CJO 2014 doi:Io.IoI7/Sooo7I234I4000I92

Muturi, J.B. 20I2. "Foreword". in Creating Effective Party-Based Communication: A Guideline for Preparing a Communication Strategy for Political Parties. http://dipd.dk/wp-content/uploads/Creating-Effective-Party-Based-Communication-A-Guideline-for-Preparing-a-Communication-Strategy-for-Political-Parties.-CMD-Kenya-Oct.-20I2.pdf

Nancy, Jean-Luc. 2013. "Hatred, a Solidification of Meaning”. https://www. 
coe.int/t/dghl/standardsetting/media/Belgrade2or3/JL\%20Nancy,\%20Hatred \%20a\%20Solidification\%20of\%2oMeaning_en.pdf

NDI. 200I. Political Parties and The Transition to Democracy: A Primer in Democratic Party-Building for Leaders, Organizers and Activists. The National Democratic Institute for International Affairs (NDI) September 200I.

20I5. Statement of the National Democratic Institute's International Observer Mission to Nigeria's March 28 Presidential and Legislative Elections, March 30.

Norris P., Curtice J, Sanders D, Scammell M and Semetko HA. I999. On Message: Communicating the Campaign. London: Sage.

Norris, Pippa. 2000. A Virtuous Circle. Political Communications in Postindustrial Societies. New York: Cambridge University Press. 2005. Political Parties and Democracy in Theoretical and Practical Perspectives Developments in Party Communications. National Democratic Institute for International Affairs (NDI). http://www.ndi.org/

Okereke, C. Nna-Emeka. 2012. Anatomy of Elections and National Security in Nigeria. http://www.internationalpeaceandconflict.org/profiles/ blogs/elections-and-security\#.Vo8hOhUrLIU

Olurode, 'Lai. 20I4. “Understanding a 'Power Broker': The Road Transport Workers Unions in the Context of Election Security". in Olurode, 'Lai (ed) Election Security: Stakeholders' Perspectives, Published by Independent National Electoral Commission (INEC) and FriedrichEbert-Stiftung (FES), Nigeria.

Omilusi, Mike. 2015. Deconstructing the Philosophical and Socio-Political Underpinnings of Electoral Behaviour in Ekiti State, Nigeria. A paper presented at a Two-Day National Conference on "The 20I5 General Elections in Nigeria: The Real Issues", Organised by The Electoral Institute, Abuja, Nigeria, July 27-28, 2015.

Omoh, Gabriel. 2013. "Nigeria's Politics of Zero-Sum Game”. Vanguard, July 29

Omotola, Shola and Nyuykonge, Charles. 20I5. "Nigeria's 2015 general elections: Challenges and opportunities". Policy \& Practice Brief, ACCORD, March 20I5.

Osun Defender. 20I5. 'Valentine' elections and Drums of war, Like the Asari Dokubos of the world threatening..." January 29.

Peoples Daily. 20I5. March Polls: Propaganda, Hate Speeches but Where are the Issues? March 9.

Pfau, Michael and Kenski, Henry C. I990. Attack Politics, New York: Praeger 
Premium Times. 2013. There will be Bloodshed if Jonathan Loses in 2015, says Asari-Dokubo, September 9

20I5. Patience Jonathan is right; Buhari is brain-dead - Jonathan campaign, March 5 .

20I5. PDP Crisis: Party blames "hate campaign" for Jonathan's defeat; opens up on campaign funding, May 4.

. 20I5. "Why we published Ayo Fayose's 'death' advert on Buhari" - The Sun, May 8.

Rao, Sumedh. 20I4. "Dealing with Election-Related Violence in Fragile and Conflict-Affected States". GSDRC Helpdesk Research Report II26. Birmingham, UK: GSDRC, University of Birmingham. http:// www.gsdrc.org/go/display\&type=Helpdesk\&id=II26

RealNews Magzine. 20I5. Worries over Hate Campaigns, March 30.

Report of The Electoral Reform Committee. 2008. Volume in Main Report, http://eie.ng/wp-content/uploads/20I4/03/JusticeMohammedUwaisReport.pdf

Römmele, Andrea (2003) "Political Parties, Party Communication and New Information and Communication Technologies," Party Politics, 9 (January 2003), 7-20.

Russmann, Uta. 2012. “Going Negative \& Going Positive: Political Parties' Communication Strategies in Election Posters, Campaign Advertisement and Press Releases during the 2008 Austrian National Election Campaign", Paper prepared for presentation at the 22nd IPSA World Congress of Political Science, Madrid, 8-I2 July 2012

Sartori, Giovanni. I976. Parties and Party Systems: A Framework for Analysis. New York and Cambridge: Cambridge University Press

Semetko, Holli A. 20I0. "Election Campaigns, Partisan Balance, and the News Media”. in Pippa Norris (ed.) Public Sentinel: News Media Q Governance Reform. The International Bank for Reconstruction and Development / The World Bank. http://siteresources.worldbank. org/EXTGOVACC/Resources/PublicSentineleBook.pdf

Shale, V. 20Io. Regional Perspective on the Role of Non-State Actors in Development Policy Agenda. Maseru: TRC.

The City Reporters. 20I5. "PDP will not respond to Bakare, Mbaka" - Metuh, January 5 .

The Nation. 20I4. PDP's Janjaweed Comment, March I4.

The United States Holocaust Memorial Museum. 2009. "Hate Speech and Group Targeted Violence: The Role of Speech in Violent Conflicts". http://www.overcominghateportal.org/uploads/5/4/I/5/54I5260/ 
hate_speech_and_targeted_violence.pdf

This Day. 20I4. APC to PDP: Stop Blackmailing us with Religion, March io . 20I5. "APC Ups the ante, insist on parallel government if election is rigged", Newspaper, January, 5.

2015. Buhari's Brain is Dead, Says Patience Jonathan, March 4 . 2015. Minimising Electoral Violence, Enhancing National Development (Nigeria), February I2.

2015. PDP Blames Jonathan's Defeat on Hate Campaign, May 5.

Thisday. 20I4. "Akpabio's Ungubernatorial Demeanour", 25 July 2014.

Titley, Gavan. 20I4. "Hate speech Online: considerations for the proposed campaign". in Titley, Gavan et al (eds.) Starting Points for Combating Hate Speech Online: Three Studies About Online Hate Speech and Ways to Address it. Council of Europe, October 20I4.

Tsav, Abubakar. 20I5. "Tsav Blames Patience Jonathan, Fani-Kayode, Fayose for PDP's Defeat”, Daily Post, March 6.

Tulkens, Françoise. 20I3. "The Hate Factor in Political Speech - Where Do Responsibilities Lie?”. Report of the Council of Europe Conference, Warsaw, I8-i9 September.

Udogu, Ike E. I995. "The Military, Civil Society and the Issue of Democratic Governance Toward Nigeria's Fourth Republic”. Journal of Developing Societies, Vol. XI, 2.

Ukah, Asonzeh. 2015. "What about Religion" in Nigeria: What Is To Be Done? https://africaisacountry.atavist.com/nigeriawhatistobedone

NigerianEye. 20I4. "Buhari is a Religious Bigot and a Non-issue" - Doyin Okupe, December I7.

Premium Times. 20I5. APC Campaign Expresses Worries over Alleged Plans to Scuttle Buhari's Victory, January I7 .

The Sun. 20I5. Buhari wants NTA, AIT Sanctioned Over Alleged Hate Campaign. February 2.

Vanguard. 20I4. APC has Janjaweed Ideology Against the Nation - PDP, May 27.

. 2015. Alleged Hate message: Buhari Takes Patience Jonathan to ICC, March 9.

2015. Death Wish Advert: NHRC to Sanction Fayose, January 22. 


\begin{abstract}
Until a few months to the 2015 general elections, many political parties that have conveniently hibernated for a better part of their existence, perhaps owing to lack of proper organizational structure or support base, uncoordinated programmes or were registered because of pecuniary gains or admittance of anticipated poor electoral outing, suddenly began to jostle for political space. The main opposition party and the ruling party were either perfecting a merger processes or engulfed in internal wrangling such that communication with the electorate on fundamental issues became inconsequential. In fact, the two dominant parties, the Peoples Democratic Party and All Progressive Congress only produced their presidential candidates less than five months to the election; and the electoral campaign assumed desperate contestation in a climate of prejudice and intolerance. Hate speeches and violence were the hallmarks of their electoral campaigns. The 2015 general elections therefore, offer a unique context to interrogate the place of party political communication in an emerging democracy and specifically how hate campaigns among political gladiators/contending parties could generate violence, and if not tamed, derail democratic consolidation. This essay affirms that hate speech is not only inspired by some social circumstances but also part of a general democratic process. It attests to the fact that Nigerian politicians have become more desperate and daring in taking and retaining political power; and more intolerant of opposition, criticism and efforts at replacing them. Relying extensively on secondary sources with the aid of descriptive and narrative tools, this essay concludes that the political culture of a country determines the behavior and attitude of the population towards the political system and that democratic transition from one administration to another, particularly in emerging democracies, has often been accompanied by violence promoted by desires of the political party in power to consolidate their grips on power and by opposition parties interest to capture same.
\end{abstract}

\title{
KEYWORDS
}

Political Communication; Hate speech; Political Party; Election; Campaign.

Received on November 9, 2017. Approved on December 11, 2017. 